\title{
Perceived Values of the Potentials of Mountains and Hills for the Development of Tourism in Ekiti State Southwest Nigeria
}

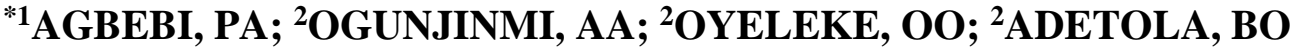

\author{
${ }^{*}$ Department of Hospitality, Leisure and Tourism, Moshood Abiola Polytechnic, Abeokuta, Ogun State, Nigeria. \\ ${ }^{2}$ Department of Ecotourism and Wildlife management, School of Agriculture and Agricultural Technology, Federal University of \\ Technology, Akure Ondo State, Nigeria \\ "Corresponding Author Email: agbebipius@gmail.com
}

\begin{abstract}
This study examined the perceived values of the potentials of mountains and hills for the development in Ekiti State. A multi-stage sampling technique was used to select 500 respondents from community residents and 384 visitors while questionnaires were used to collect data. Data were analyzed using frequency, percentages, and means, while inferential statistical tools such as t-test, Chi-square, correlation coefficient and regression were used to test the hypotheses. The results of the hypotheses showed that there was statistically significant difference between the way community residents and visitors perceived the values of mountains and hills tourism development in Ekiti State in terms of non-use value $\left(t=5.06^{* *}, p<0.01\right)$, recreation value $\left(t=6.63^{* *}, p<0.01\right)$, intrinsic value $\left(\mathrm{t}=8.68^{* *}, \mathrm{p}<0.01\right)$, use value $\left(\mathrm{t}=2.77^{* *}, \mathrm{p}<0.01\right)$. The implication of the study is that the development of mountains and hills tourism in these communities will create both positive and negative responses arising from their varied opinions which will help to shape the entire structure and its future growth and development. It was recommended that the government of Ekiti should partner with the interested individuals and private sectors to develop mountains and hills in Ekiti communities so as to give tourism a jolt to prominence.
\end{abstract}

\section{DOI: https://dx.doi.org/10.4314/jasem.v25i3.22}

Copyright: Copyright (C) 2021 Agbebi et al. This is an open access article distributed under the Creative Commons Attribution License (CCL), which permits unrestricted use, distribution, and reproduction in any medium, provided the original work is properly cited.

Dates: Received: 12 December 2020; Revised: 26 January 2021; Accepted: 12 February 2021

Keywords: Communities, Visitors, non-use, recreation, intrinsic, use

Tourism generally has become a global leisure activity, and has to its credit virtually uninterrupted growth over time despite occasional shocks, demonstrating the sector's strength and resilience which could be seen in the International tourist arrivals' increase from 25 million globally in 1950 to 278 million in 1980, 674 million in 2000, and 1.19 billion in 2015 (UNWTO, 2016). According to UNWTO (2020), the latest data reported by destinations around the world shows that estimated international tourist arrivals (overnight visitors) worldwide increased by $4 \%$ in 2019 to reach 1.5billion. All regions of the world enjoyed an increased arrivals with Middle East $(+8 \%)$ which led growth, followed by Asia and Pacific (+5\%). International arrivals in Europe and Africa (both $+4 \%$ ) increased in line with the world average, while the Americas saw growth of $2 \%$. This trend will continue to occur as many visitors are eager to travel far and wide in search of leisure and business opportunities. Mountains and hills tourism is a type of tourism activity which occurs in a defined and limited geographical space of mountains and hills with distinctive characteristics and attributes that are inherent to a specific landscape, topography, climate, biodiversity and local community. It comprises a broad range of outdoor leisure and sport activities; an attributes that position it for frequently patronized segment of tourism sector worldwide (UNWTO, 2019). Debarbieux and Gillie (2014) opined that mountains and hills regions provide sites of some of the earliest forms of tourism: in the 18th century the Alps became an essential stop for English aristocrats, when it became fashionable to make the "Grand Tour". Debarbieux et al. (2014) further explained that associated qualities have now become assets, valuable for the development of mountain tourism: snow, with the invention and spread of skiing; the diversity of local peoples and traditional cultural practices; the abundance of mineral and hot springs; the sacred dimension attributed to many mountain sites and summits; biological and geological diversity, reflected in unique geological formations and plant communities, as well as emblematic animal species, such as chamois, ibex, mountain lions, and pandas. All of these resources will likely take on increasing importance in the coming decades, as urbanization exerts a growing impact on our world and lifestyles, and the appeal of travel and tourism continues to expand. Nigeria is not left out in this regard; Obudu 
Mountains resort in Cross-river State is now a beehive of interesting activities that provide pleasure and comfort for some categories of tourists in Nigeria and other international tourists. Many families visit this area to spend their holidays and participate in various interesting and beneficial leisure activities for their rejuvenation and psych well-being. Ekiti State is dotted with Rocky Mountains and hills of various types, shapes and sizes wonderfully positioned in some communities across the state. Their appearances are so captivating and enchanting that one would wish to have enough leisure time and sufficient money to tour and savour the beauty nature that God has endowed Ekiti State (Igbokwe, 2013).

Mountains and hills tourism is a type of activity which take place in a defined and limited geographical space such as hills and mountains with distinctive characteristics and attributes that are inherent to a specific landscape, topography, climate, biodiversity and local community (UNWTO, 2019). Mountain and Hill tourism is a new sector in tourism which is gradually increasing it's positioning within the assortment of forms of tourism that we have and showing a rapid development throughout the world in recent decades. Mountain areas have currently established themselves as the second most visited visitors and tourists destinations, and as well contributing to $15-20 \%$ of tourism worldwide, which represents between 70 and 90 billion dollars per year (Mohd, et al., 2015). Today, the upsurge in visitor flows, the distribution of these spaces, the rise in accessibility and the adaptation of the necessary infrastructure make mountain and hill spaces beyond a religious thing, and somewhat spaces for leisure and sports. Specifically, in the 19th century, mountain and hill areas, especially the Swiss Alps, were the main relaxation and free time centres for the rich classes of Europe (Flognfeldt, Tjørve, 2013). The paper assessed the perceived values of mountains and hills potentials for tourism development in Ekiti State.

\section{MATERIALS AND METHODS}

The Study Area: Ekiti State is located in Southwest Nigeria (Figure 1). The State is located on Longitude $5.2500^{\circ} \mathrm{E}$ and Latitude $7.6667^{\circ} \mathrm{N}$. It lies south of Kwara and Kogi State, East of Osun State and bounded by Ondo State in the East and in the South. The land Area is $5,887.890 \mathrm{sq} \mathrm{km}$. The State enjoys tropical climate with two distinct seasons. These are the rainy season (April-October) and the dry season (November-March). The annual rainfall values in Ekiti in the last 20 years ranges between $996.4 \mathrm{~mm}$ minimum to $1549.4 \mathrm{~mm}$ maximum (Owolabi, 2016).
Temperature ranges between $21^{\circ}$ and $28{ }^{\circ} \mathrm{C}$ with high humidity which ranges between $65-100 \%$ during the dry and wet season respectively. The south westerly wind and the northeast trade winds blow in the rainy and dry (Harmattan) seasons respectively. The land of Ekiti is known for its forest resources, notably timber. However, because of favourable climatic conditions, the land enjoys luxuriant vegetation. The flora composition in Ekiti State includes trees species such as Acacia albida Delile (Mimosaceae), Albizia fernginea (Mimosaceae), Alstonia boonei De wild (Apocynaceae), Berlinia coriacea Keay (Caesalpiniaceae), Antiaris toxicaria Lesch (Moraceae), celtris zenkeri Engl (Ulmaceae), Melicia exlcesa (Welw) Benth (Moraceae), Khaya grandifoliola C.DC. (Meliaceae), etc. Also, animal species such as grass-cutter (Thyronomys swinderianus), Maxwell duiker (Cephalophus maxwelli), Bush pig (Potamochoerus porcus), ground squirrel (Protoxerus stranger), African giant rat (Cricetomys gambianus), Bush buck (Tragelaphus scriptus), etc. are predominant in the area.

The occupation of indigenes of Ekiti State is predominantly farming because the land enjoys favourable climatic conditions with luxuriant vegetation, where food crops such yam, cocoyam, cassava, rice, and maize are grown in large quantities. There are other notable crops like Cocoa and Kolanut, while and other varieties of fruits such oranges, pineapples, cashew, Plantain, Bananas etc. are cultivated in commercial quantities. As a matter of fact, Ekiti people are culturally homogeneous and speak a dialect of Yoruba language known as Ekiti. The study was conducted in 27 selected communities with mountains and hills. The communities were Ado Ekiti, Ilokun, Efon Alaaye, Obake, Orisumibare, and Oba Ayetoro (Efon Local Government Area), Ijero and Epe (Ijero Local Government Area), Aramoko, Erio, and Okeimesi (Ekiti West Local Government Area), Iyin, Iworoko, Igede (Ifelodun/Irepodun Local Government Area), Igbole Ekiti (Ido/Osi Local Government Area) Abaoke-Ilabo (Ikole Local Government Area), Ewu (Ilejemeje Local Government Area) Ilupeju and Apata-Aje (Oye Local Government Area), Ilawe and Igbara-Odo, Ikogosi, Ipole-Iloro (Ekiti Southwest Local Government Area), Ikere Ekiti, Atoka, Oke Aso, and Okejegbende (Ikere Local Government Area). (Figure 1). Tourists centres visited include; Fajuyi park, Ewi palace, Erinta Waterfall, Orole/Olosunta, Erio mountain, Erin Ayorigba sacred fish, Ido-Ajinare mountain, Esa cave, Ikogosi warm spring, Ero Dam, Egbigbu Artificial Lake, Ooni Rivers, Oroke Ewo. 


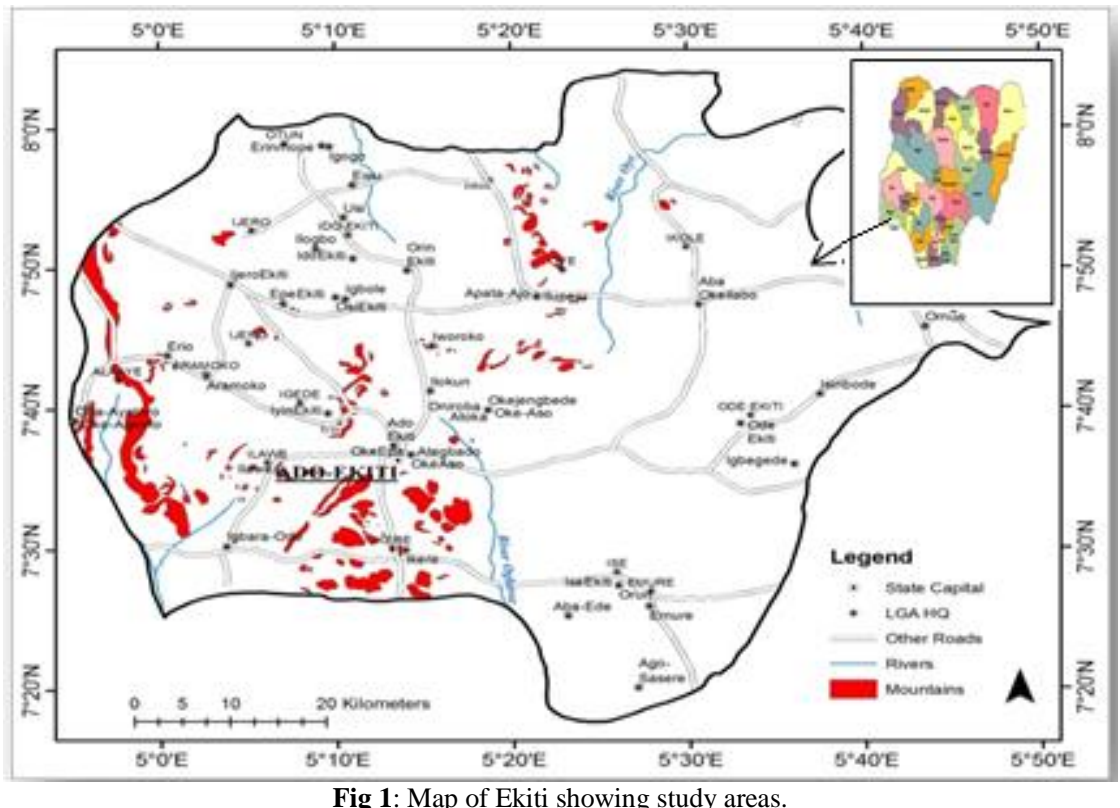

Source: Field Survey, 2019

Methods: In taking a sample size of the community with hills and mountains in Ekiti State, a systematic sampling technique known as multi-stage sampling was adopted. Two stages were involved; First stage was to divide Ekiti into 3 zones; Ekiti Central, Ekiti North and Ekiti South. In stage two, 27 communities were selected from the zones through purposive sampling while 1991 National Population census of communities in Ekiti State was used to project 2019 figures for each of the selected communities at $3.15 \%$ increase per annum. Thus, there were a total of One million and sixty two thousand and seventy two $(1,062,072)$ projected 2019 population figures in 27 towns and communities under study. Also, for visitors, the recorded population of visitors that visited the sites in 2018 was obtained from staff managing the sites $(188,357)$ and this was subsequently used to determine the sample size of respondents at each destination. The sample size of the communities and visitors were 500 and 384 respectively.

Questionnaire administration was used as instrument for the collection of data. Data collected were analyzed using descriptive tools such as frequency, percentages and means while hypotheses were tested using t-test, chi-square, PPMC, and Multi-linear regression. Variables measured in this study include gender, age, occupation, marital status, education, religion, nationality, ethnicity, income, experience. Perceived values of mountains and hills were measured in 7 Likert Scale of Strongly Agreed (SA) 7, Agreed (A) 6, Slightly Agree (SA) 5, Undecided (U) 4, Disagree (D) 3, Slightly Disagree (SD) 2, and Strongly Disagree (SD) 1 .

\section{RESULTS AND DISCUSSION}

Socio-demographic characteristics of respondents: The male respondents out-numbered female respondents from the communities. The male respondents from the communities were 327 (65.4\%) while female respondents were 173 (34.6\%). The implication of this disparity is that more men are actively disposed to mountains and hills tourism and other social activities than women. Another interesting area of respondents' socio-demographic feature is their age. The average age of all the respondents in the communities is 41years which implies that there were more young men and women respondents in the communities which fall between $25-54$ years or $60.8 \%$. Thus, these people would be more favourably disposed to visiting mountains and hills for touristic purpose. Marital status of respondents is pertinent to the study because it will elucidate individuals or groups of potential and existing patrons of mountains and hills tourism in Ekiti State. And this will help in the preparation and setting up of desirable mountains and hill tourism destinations in the State. From the demographic features of respondents from community, it was observed that married people have the highest number of respondents with 265 (53\%), followed by single with $147(29.4 \%)$, separated $31(6.2 \%)$, widowed 57 $(11.4 \%)$. This implied that there were more married and singles individuals in the communities who are inclined to partaking in tourism activities. The educational status of respondents from the communities was quite encouraging; 314 (62.8\%) attended tertiary institutions, $163(32.6 \%)$ attended secondary school, $13(2.6 \%)$ attended primary school 
while $10(2.0 \%)$ were without formal education. The implication of this is that mountains and hills tourism in Ekiti State are likely to attract more existing and potential visitors and tourists that are highly educated. This will further gives mountains and hills tourism development in Ekiti a jolt to expansion and prominence. The occupational status of respondents is of great importance to the development of mountains and hills tourism in Ekiti State. From the community, the occupational status of respondents put the students at $122(24.4 \%)$, self-employed $89(17.8 \%)$, public sector 165 (33\%), private sector $32(6.4 \%)$, unemployed $2(0.4 \%)$, retired $35(7 \%)$, farming 55 $(11 \%)$. The issue of monthly income of respondents is another important factor in mountains and hills tourism in Ekiti State. From the community, it was discovered that few number of people were in the region of higher income earners; $236(47.2 \%)$ while the remaining $264(52.8 \%)$ are in the category of average and low income earners. However, as economy of the communities continues to grow through the development of mountains and hills, and the impressive inflow of money within the community, the residents will be inclined to willingly patronize mountains and hills in the state.

Socio-demographic characteristics of Visitors: The male respondents from tourist sites were 228 while female respondents were 156 representing $59.4 \%$ and $40.6 \%$ respectively as illustrated in table 15 . From tourist' sites, it was observed that there were more male than female visitors. This could be due to the fact that men are more inclined to tourism activities than women. Another interesting area of respondents' socio-demographic characteristics is their age which showed that there were more young men and women respondents from the communities which falls between 25-54years. Thus, these people are in their active years and would be more favourably disposed to visiting mountains and hills for touristic purpose. Married, 225 (58.6\%), widowed, 80 (20.8\%), single, $37(9.6 \%)$ and separated 42 (10.9) individuals are inclined to tourism activities. However, married people have the highest number of existing visitors to tourism destinations. As regard the educational status of the visitors, $322(83.9 \%)$ attended tertiary institutions, $46(12.0 \%)$ attended secondary school while $16(4.2 \%)$ went to primary school. In this circumstance, mountains and hills tourism in Ekiti State will receive an impressive boost from educated tourists who will give the sector a realistic future and encourage more development and expansions that will lift Ekiti State from its present economic quagmire. The occupational status of visitors/tourists stood at; student $30(7.8 \%)$, self- employed $140(36.5 \%)$, public sector $62(16.1 \%)$, private sector $48(12.5 \%)$, retired $96(25.0 \%)$, farming $8(2.1 \%)$. The self-employed tourists constituted the largest group of visitor/tourists in this circumstance. This shows that they have enough leisure time and high disposable income that will enable them to embark on tourism activities. From the visitors and tourists, it was discovered that few number of people are in the region of higher income earners; $42(9.6 \%)$ while the remaining $393(90.4 \%)$ are in the category of average and low income earners. However, as economy of the communities continues to grow through the development of mountains and hills, and impressive inflow of money within the communities, the residents will be inclined to willingly patronize mountains and hills in the state.

Socio-demographic characteristics of Respondents: Travelling Experience, Motivation and Activities: The travelling experience of the residents of the communities to destinations of interest showed that quantum number $(92.2 \%)$ of them have had such experience while about $8 \%$ had not travelled to destinations of interest for purpose of recreation. However, these people are motivated to destinations for health development, spiritual fulfillment, to enjoy serene environment with fresh and clean air, and also to escape boredom. It is interesting to know that many of them engaged in activities such as site-seeing, education tour, mountaineering, hillwalking, wildlife viewing etc:

Differences between Perceived values of mountains and hills by the community residents and visitors: The perceived values of mountains and hills tourism were measured and rated on 7 Likert scale of; Strongly Agree (SA) Agree (A) Slightly Agree (SA Undecided (U) Disagree (D) Slightly Disagree (SD) Strongly Disagree (SD). They were viewed from four dimensions namely; non- use value, recreation values, intrinsic values, and use values. From the perception of non- use values of mountains and hills, the communities have a mean value of 4.67 and standard deviation of 2.101. This result implied that many communities agreed to the non-use values of mountains and hills tourism development and therefore will boost its development in Ekiti State. On the recreational values of mountains and hills tourism, the mean value from respondents was 5.04 while the standard deviation was 2.159. The implication of this result is that there was strong agreement to the recreation values of mountains and hills by the communities. Thus, the support for the development of mountains and hills tourism potentials in the State. From the angle of intrinsic values, there was mean values of 5.03 and standard deviation of 2.021. 
Table 1 (a) Respondents from Communities Table 1 (b) Respondents from Visitors

\begin{tabular}{|c|c|c|c|c|c|}
\hline & $\mathbf{A}$ & & & B & \\
\hline $\begin{array}{l}\text { Variable } \\
\text { Gender }\end{array}$ & Frequency & Percentage & $\begin{array}{l}\text { Variable } \\
\text { Gender }\end{array}$ & Frequency & Percentage \\
\hline Male & 327 & 65.4 & Male & 228 & 59.4 \\
\hline Female & 173 & 34.6 & Female & 156 & 40.6 \\
\hline Age (years) & & & Age (years) & & \\
\hline $15-24$ & 39 & 7.8 & $15-24$ & 31 & 8.1 \\
\hline $25-54$ & 304 & 60.8 & $25-54$ & 152 & 39.6 \\
\hline $55-64$ & 139 & 27.8 & $55-64$ & 143 & 37.2 \\
\hline 64 above & 18 & 3.6 & 65 above & 58 & 15.1 \\
\hline Marital status & & & Marital status & & \\
\hline Married & 265 & 53 & Married & 225 & 58.6 \\
\hline Single & 147 & 29.4 & Single & 37 & 9.6 \\
\hline Separated & 31 & 6.2 & Separated/divorced & 42 & 10.9 \\
\hline widowed & 57 & 11.4 & Widowed & 80 & 20.8 \\
\hline Education status & & & Educational status & & \\
\hline Tertiary & 314 & 62.8 & Tertiary & 322 & 83.9 \\
\hline Secondary & 163 & 32.6 & Secondary & 46 & 12.0 \\
\hline Primary & 13 & 2.6 & Primary & 16 & 4.2 \\
\hline Non formal & 10 & 2.0 & Occupational status & & \\
\hline Occupational status & & & Student & 30 & 7.8 \\
\hline Student & 122 & 24.4 & Self -employed & 140 & 36.5 \\
\hline Self-employed & 89 & 17.8 & Public sector & 62 & 16.1 \\
\hline Public sector & 165 & 33.0 & Private sector & 48 & 12.5 \\
\hline Private sector & 32 & 6.4 & Retired & 96 & 25.0 \\
\hline Unemployed & 2 & 0.4 & Farming & 8 & 2.1 \\
\hline Retired & 35 & 7.0 & Religion & & \\
\hline Farming & 55 & 11.0 & Christian & 268 & 69.8 \\
\hline Religion & & & Islam & 111 & 28.9 \\
\hline Christianity & 315 & 63.0 & Traditional & 5 & 1.3 \\
\hline Islam & 157 & 31.4 & Monthly income (N & & \\
\hline Traditional & 28 & 5.6 & Less than 30,000 & 15 & 3.9 \\
\hline $\begin{array}{l}\text { Monthly income ( } \\
\text { Naira:\#) }\end{array}$ & & & $\# 31,000-\# 60,000$ & 95 & 24.7 \\
\hline Less than 30,000 & 71 & 14.2 & $\# 61,000-\# 90,000$ & 113 & 29.4 \\
\hline $31,000-60,000$ & 193 & 38.6 & $\# 91,000-\# 120,000$ & 72 & 18.8 \\
\hline $61,000-90,000$ & 182 & 36.4 & $\# 121,000-\# 150,000$ & 53 & 13.8 \\
\hline $91,000-120,000$ & 38 & 7.6 & 150,000 and above & 36 & 9.4 \\
\hline $121,000-150,000$ & 6 & 1.2 & Nationality & & \\
\hline & & 2.0 & Nigerian & 382 & 99.5 \\
\hline Nationality & & & Non Nigeria & 2 & 0.5 \\
\hline Nigerian & 482 & 96.4 & Ethnicity & & \\
\hline Non Nigeria & 18 & 3.6 & Yoruba & 231 & 60.2 \\
\hline Ethnic group & & & Ibo & 108 & 28.1 \\
\hline Yoruba & 398 & 79.6 & Hausa & 45 & 11.7 \\
\hline Ibo & 86 & 17.2 & Travelling Exp. & & \\
\hline Hausa & 16 & 3.2 & YES & 354 & 92.2 \\
\hline Native Status & & & NO & 30 & 7.8 \\
\hline Native & 288 & 57.6 & Destinations & & \\
\hline Non native & 212 & 42.4 & None & 30 & 7.8 \\
\hline & & & Obudu Mt. resort & 106 & 27.6 \\
\hline Length of stay & & & Erio prayer mountain & 165 & 43.0 \\
\hline $0-5 y r s$ & 10 & 2.0 & Olosunta / Orole in Ikere & 11 & 2.9 \\
\hline $6-10 y r s$ & 102 & 20.4 & Ido Ajinare prayer mt. & 16 & 4.2 \\
\hline $11-15 y r s$ & 140 & 28.0 & Idanre hills & 56 & 14.6 \\
\hline $16-20 y r s$ & 118 & 23.6 & Member of NGOs & & \\
\hline more than $20 \mathrm{yrs}$ & 130 & 26.0 & Yes & 67 & 17.4 \\
\hline Travelling Experience & & & No & 317 & 82.6 \\
\hline YES & 223 & 44.6 & Motivation & & \\
\hline NO & 277 & 55.4 & Health development & 109 & 28.4 \\
\hline NGOs & & & Spiritual fulfillment & 128 & 33.3 \\
\hline YES & 10 & 2.0 & Fresh and clean air & 41 & 10.7 \\
\hline NO & 490 & 98.0 & Escape boredom & 106 & 27.6 \\
\hline CDA & & & Activity & & \\
\hline YES & 207 & 41.4 & Site-seeing & 88 & 22.9 \\
\hline \multirow[t]{4}{*}{ NO } & 293 & 58.6 & Education tour & 77 & 20.1 \\
\hline & & & Mountaineering & 58 & 15.1 \\
\hline & & & Hill walking & 55 & 14.3 \\
\hline & & & Wildlife viewing & 106 & 27.6 \\
\hline
\end{tabular}

Source: Field Survey, 2019.

This was an indication that respondents strongly agreed to the intrinsic values of mountains and hills tourism development. From the dimension of use values of mountains and hills tourism potentials, the mean value was 4.92 and standard deviation of 1.945 .
This result also showed that respondents slightly agreed to the use values of mountains and hills. This means that there was strong support for the development of mountains and hills tourism in Ekiti State. Similarly, from visitors' perspective, they 
supported the development of mountains and hills tourism potentials in Ekiti State through their perceived values; on non-use values of mountains and hills tourism potentials, the visitors response mean value was 4.18. This was an indication that the visitors slightly agreed to the non-use value of mountains and hills tourism potentials. From the dimension of recreation values, there was a response mean value of 4.34 and standard deviation of 1.883 . This result also shows that visitors slightly agreed to the recreation values of mountains and hills tourism. On the issue of intrinsic values of mountains and hills tourism, there was a response mean value of 4.21 and standard deviation of 2.019. This result falls within the two previous results showing that respondent slightly agreed. On the use values of mountains and hills tourism potentials, the visitors' response mean value was 4.69 while the standard deviation was 1.857 . This indicated that there was a slight agreement to the use values. These values are distinctly illustrated in table 3.

Table 2: Differences between community residents and visitors' perceived values of mountains and hills for tourism development in Ekiti State

\begin{tabular}{|c|c|c|c|}
\hline Perceived Value Statement & $\begin{array}{l}\text { Community } \\
\text { Mean value }\end{array}$ & $\begin{array}{l}\text { Visitor } \\
\text { Mean value }\end{array}$ & $\begin{array}{l}\text { t- } \\
\text { value }\end{array}$ \\
\hline NON- USE VALUE & 5.03 & 4.70 & \\
\hline 1.Mountains and hills areas are valuable to keep for future generations of humans & 3.56 & 3.41 & \\
\hline 2. I'm seeing mountains and hills areas the next generation of children may not see. & & & \\
\hline 3. I need to know that untouched, mountains and hills areas exist. & 5.18 & 3.97 & \\
\hline 4. There are plenty of mountains and hills areas that are not very nice to visit. & 5.35 & 4.35 & \\
\hline 5. We have to protect the mountains and hills environment for humans in the future. & 5.13 & 4.51 & \\
\hline $\begin{array}{l}\text { 6. Even if I don't go to mountains and hills areas, I can enjoy them by looking at books } \\
\text { or seeing films. }\end{array}$ & 3.82 & 4.14 & \\
\hline Total mean values & 28.08 & 25.10 & $5.06^{* *}$ \\
\hline \multicolumn{4}{|l|}{ RECREATION VALUE } \\
\hline 1. I value mountains and hills places for my spare time activities & 5.05 & 3.87 & \\
\hline 2. The mountains and hills environment is valuable for my leisure & 5.03 & 4.74 & \\
\hline 3. Mountains and hills are important to me because I used them for recreation & 5.06 & 4.53 & \\
\hline 4. Mountains and hills areas must be protected because I might want to use them. & 5.06 & 4.17 & \\
\hline 5. I value mountains and hills areas mainly for their use to me for my sport and hobbies & 4.98 & 4.39 & \\
\hline Total mean values & 25.17 & 21.74 & $6.63^{* *}$ \\
\hline \multicolumn{4}{|l|}{ INTRINSIC VALUE } \\
\hline 1. The only value that mountains and hills area has is what humans can make from it & 4.98 & 4.61 & \\
\hline 2. Ugliness in nature indicates that an area has no value. & 5.36 & 4.50 & \\
\hline 3. The value of mountains and hills only depends on what it does for humans & 5.49 & 4.26 & \\
\hline 4. The value of nature exists only in the human mind & 4.55 & 3.99 & \\
\hline 5. Without people mountains and hills has no value. & 5.26 & 4.21 & \\
\hline Total mean values & 25.64 & 21.59 & $8.68^{* *}$ \\
\hline \multicolumn{4}{|l|}{ USE VALUE } \\
\hline $\begin{array}{l}\text { 1. I don't like industries such as mining destroying parts of mountains and hills, but } \\
\text { it is necessary for human survival. }\end{array}$ & 4.80 & 5.39 & \\
\hline $\begin{array}{l}\text { 2. Native mountains and hills forests are valuable because they produce income for } \\
\text { people. }\end{array}$ & 5.34 & 4.59 & \\
\hline $\begin{array}{l}\text { 3. To say that mountains and hills areas have value just for themselves is a nice idea } \\
\text { but we just cannot afford to think that way: the welfare of people has to come first. }\end{array}$ & 5.38 & 4.54 & \\
\hline $\begin{array}{l}\text { 4. Mountains and hills are precious and worth preserving but human needs are } \\
\text { sacrosants. }\end{array}$ & 5.46 & 4.43 & \\
\hline $\begin{array}{l}\text { 5. Our children will be better off if we spend money on industry rather than on } \\
\text { mountains. }\end{array}$ & 3.63 & 4.51 & \\
\hline Total mean values & 24.61 & 23.46 & $2.77 * *$ \\
\hline
\end{tabular}

Table 3. Significant difference between communities and visitors' perceived value (t-test method)

\begin{tabular}{llll}
\hline $\begin{array}{l}\text { Perceived value } \\
\text { statement }\end{array}$ & $\begin{array}{l}\text { Mean value for } \\
\text { communities }\end{array}$ & $\begin{array}{l}\text { Mean value for } \\
\text { visitors }\end{array}$ & t-value \\
\hline Non-use value & 4.68 & 4.18 & $5.08^{* *}$ \\
Recreation value & 5.03 & 4.35 & $6.83^{* *}$ \\
Intrinsic value & 5.13 & 4.32 & $8.68^{* *}$ \\
Use value & 4.92 & 4.69 & $2.77^{* *}$ \\
\hline \multicolumn{4}{l}{ Source: Field Survey, 2019 }
\end{tabular}

Relationship between socio demographic their perceived value of mountains and hills characteristics of community residents, visitors and development in Ekiti State: To test whether there is 
significant relationship between the perceived value of mountains and hills by the community" residents and visitors and their socio demographic characteristics measured at nominal level, Chi-square $\left(\mathrm{X}^{2}\right)$ test was conducted. The results showed that; gender, education, occupation, religion, nationality, ethnic group and experience of community residents and visitors have significant relationships with their perceived values of mountains and hills tourism development. However, while marital status of community residents have significant relationship with their perceived values of mountains and hills, that of visitors does not have significant relationship. Furthermore, natives and non-natives in the communities have relationships with perceived values.

Table 4: Table 4. Relationship between socio-demographic characteristics of communities and Visitors

\begin{tabular}{|c|c|c|c|c|c|c|c|c|c|c|}
\hline & \multicolumn{5}{|c|}{ Community residents (Chi-square value) } & \multicolumn{4}{|c|}{ Visitors (Chi-square value) } & \multirow[b]{2}{*}{ Sig. } \\
\hline $\begin{array}{l}\text { Independent } \\
\text { variables }\end{array}$ & $\begin{array}{l}\text { Non-use } \\
\text { value }\end{array}$ & $\begin{array}{l}\text { Recreation } \\
\text { value }\end{array}$ & $\begin{array}{l}\text { Intrinsic } \\
\text { value }\end{array}$ & $\begin{array}{l}\text { Use } \\
\text { value }\end{array}$ & Sig. & $\begin{array}{l}\text { Non-use } \\
\text { value }\end{array}$ & $\begin{array}{l}\text { Recreation } \\
\text { value }\end{array}$ & $\begin{array}{l}\text { Intrinsic } \\
\text { value }\end{array}$ & $\begin{array}{l}\text { Use } \\
\text { value }\end{array}$ & \\
\hline Gender & $144.00^{\mathrm{a}}$ & $168.51^{\mathrm{a}}$ & $120.50^{\mathrm{a}}$ & $427.01^{\mathrm{a}}$ & 0.000 & $107.42^{\mathrm{a}}$ & $96.15^{\mathrm{a}}$ & $64.70^{\mathrm{a}}$ & $66.09^{a}$ & 0.000 \\
\hline Marital & $232.00^{\mathrm{a}}$ & $279.68^{\mathrm{a}}$ & $214.86^{\mathrm{a}}$ & $242.00^{\mathrm{a}}$ & 0.000 & $29.35^{\mathrm{a}}$ & $17.00^{\mathrm{a}}$ & $37.31^{\mathrm{a}}$ & $12.44^{\mathrm{a}}$ & 0.150 \\
\hline Education & $246.76^{\mathrm{a}}$ & $254.46^{\mathrm{a}}$ & $261.77^{\mathrm{a}}$ & $338.54^{\mathrm{a}}$ & 0.000 & $140.81^{\mathrm{a}}$ & $140.00^{\mathrm{a}}$ & $164.38^{\mathrm{a}}$ & $103.43^{\mathrm{a}}$ & 0.000 \\
\hline Occupation & $437.53^{\mathrm{a}}$ & $392.02^{\mathrm{a}}$ & $482.88^{\mathrm{a}}$ & $449.31^{\mathrm{a}}$ & 0.000 & $416.86^{\mathrm{a}}$ & $392.86^{\mathrm{a}}$ & $322.56^{\mathrm{a}}$ & $344.60^{\mathrm{a}}$ & 0.000 \\
\hline Religion & $261.22^{\mathrm{a}}$ & $299.00^{\mathrm{a}}$ & $198.34^{\mathrm{a}}$ & $246.13^{\mathrm{a}}$ & 0.000 & $246.81^{\mathrm{a}}$ & $251.36^{\mathrm{a}}$ & $196.15^{\mathrm{a}}$ & $208.14^{\mathrm{a}}$ & 0.000 \\
\hline Nationality & $153.27^{\mathrm{a}}$ & $127.93^{\mathrm{a}}$ & $100.43^{\mathrm{a}}$ & $306.08^{a}$ & 0.027 & $49.46^{\mathrm{a}}$ & $22.12^{\mathrm{a}}$ & $62.33^{\mathrm{a}}$ & $20.70^{\mathrm{a}}$ & 0.001 \\
\hline Ethnic group & $115.19^{\mathrm{a}}$ & $178.05^{\mathrm{a}}$ & $73.57^{\mathrm{a}}$ & $96.09^{a}$ & 0.014 & $190.83^{\mathrm{a}}$ & $175.47^{\mathrm{a}}$ & $156.71^{\mathrm{a}}$ & $149.86^{\mathrm{a}}$ & 0.011 \\
\hline Natives & $73.23^{\mathrm{a}}$ & $102.50^{\mathrm{a}}$ & $74.05^{\mathrm{a}}$ & $87.44^{\mathrm{a}}$ & 0.000 & & & & & \\
\hline Non native & $652.19^{\mathrm{a}}$ & $635.31^{\mathrm{a}}$ & $482.42^{\mathrm{a}}$ & $667.31^{\mathrm{a}}$ & 0.000 & & & & & \\
\hline Experience & $254.35^{\mathrm{a}}$ & $134.46^{\mathrm{a}}$ & $155.35^{\mathrm{a}}$ & $412.37^{\mathrm{a}}$ & 0.011 & $94.66^{\mathrm{a}}$ & $49.97^{\mathrm{a}}$ & $30.30^{\mathrm{a}}$ & $48.56^{a}$ & 0.002 \\
\hline NGOS & $75.20^{\mathrm{a}}$ & $57.40^{\mathrm{a}}$ & $50.47^{\mathrm{a}}$ & $249.19^{\mathrm{a}}$ & 0.289 & $155.20^{\mathrm{a}}$ & $125.04^{\mathrm{a}}$ & $80.96^{\mathrm{a}}$ & $101.15^{\mathrm{a}}$ & 0.021 \\
\hline CDAS & $101.56^{\mathrm{a}}$ & $130.65^{\mathrm{a}}$ & $86.22^{\mathrm{a}}$ & $124.72^{\mathrm{a}}$ & 0.001 & & & & & \\
\hline Destination & & & & & & $253.86^{\mathrm{a}}$ & $192.61^{\mathrm{a}}$ & $187.88^{\mathrm{a}}$ & $153.47^{\mathrm{a}}$ & 0.001 \\
\hline Motivation & & & & & & $256.08^{\mathrm{a}}$ & $187.71^{\mathrm{a}}$ & $187.01^{\mathrm{a}}$ & $194.51^{\mathrm{a}}$ & 0.000 \\
\hline Activity & & & & & & $350.91^{\mathrm{a}}$ & $321.70^{\mathrm{a}}$ & $244.69^{\mathrm{a}}$ & $233.27^{\mathrm{a}}$ & 0.000 \\
\hline
\end{tabular}

Membership of NGOs in the community residents does not have relationship with their perceived values but that of visitors has relationship. Memberships of CDAs in the community have relationship with perceived values while destination, motivation, and activity of the visitors had significant relationships with the perceived values.

Pearson's test results of the relationship between socio-demographic characteristics and perceived values of mountains and hills for tourism development by community residents and visitors: The test results of the relationship between socio-demographic characteristics and perceived values of mountains and hills for tourism development by community residents and visitors using PPMC showed that for community residents; Age had significant relationship $(\mathrm{r}=$ $\left.0.12^{* *}\right)$ with non-use value, intrinsic value $(\mathrm{r}=$ $\left.0.11^{* *}\right)$, and use value $\left(\mathrm{r}=-0.15^{* *}\right)$. But for visitors, age had relationship with non- use value $(\mathrm{r}=-0.44 * *)$, recreation value $\left(\mathrm{r}=-0.25^{* *}\right)$, Intrinsic value $(\mathrm{r}=$ $\left.0.38^{* *}\right)$ and use value $\left(\mathrm{r}=-0.45^{* *}\right)$. Income of respondents in the communities did not have significant relationship with all the perceived values. However, the situation is different with visitors where all the values had significant relationships $(0.50 * *$, $\left.0.50 * *, 0.39^{* *}, 0.27 * *\right)$. The years of stay of community residents are other important issues which had relationship with recreation value and intrinsic value, $\left(\mathrm{r}=0.14^{* *}\right.$ and $\left.\mathrm{r}=0.10^{*}\right)$. The travelling experience of community residents had relationship with the use value $\left(\mathrm{r}=0.16^{* *}\right)$. For the determinants of community residents' perceived values of mountains and hills for tourism development, marital status, education, ethnic group, experience and membership of CDAs were significant in the determinants of the total non-use value of the perceived values of mountains and hills for tourism development in Ekiti State which made the R Square to be 0.270 or $30 \%$. For total recreation value, marital status, education, and nationality determined the community residents' perceived values of mountains and hills.

Table 5: Pearson Correlation test result.

\begin{tabular}{|c|c|c|c|c|c|c|c|c|}
\hline \multirow[b]{2}{*}{$\begin{array}{l}\text { Independent } \\
\text { variables }\end{array}$} & \multicolumn{4}{|c|}{ Community residents (r-value) } & \multicolumn{4}{|c|}{ Visitors (r-value) } \\
\hline & $\begin{array}{l}\text { Non use } \\
\text { value }\end{array}$ & $\begin{array}{l}\text { Recreation } \\
\text { value }\end{array}$ & $\begin{array}{l}\text { Intrinsic } \\
\text { value }\end{array}$ & $\begin{array}{l}\text { Use } \\
\text { value }\end{array}$ & $\begin{array}{l}\text { Non-use } \\
\text { value }\end{array}$ & $\begin{array}{l}\text { Recreatio } \\
n \text { value }\end{array}$ & $\begin{array}{l}\text { Intrinsic } \\
\text { value }\end{array}$ & $\begin{array}{l}\text { Use } \\
\text { value }\end{array}$ \\
\hline Age & $-0.12^{* *}$ & -0.053 & $-0.11^{*}$ & $-0.15^{* * *}$ & $-0.44^{* *}$ & $-0.25^{* *}$ & $-0.38^{* *}$ & $-0.45^{* *}$ \\
\hline Income & 0.025 & 0.072 & 0.084 & -0.014 & $0.50^{* *}$ & $0.50^{* *}$ & $0.39^{* *}$ & $0.27^{* *}$ \\
\hline Years of stay & 0.083 & $0.14^{* *}$ & $0.10^{*}$ & 0.071 & & & & \\
\hline Experience & 0.065 & 0.047 & 0.051 & $0.16^{* *}$ & & & & \\
\hline
\end{tabular}


This showed the $\mathrm{R}$ square to be $33 \%$ determinants. As regard total intrinsic value, marital status, education, religion, nationality, ethnic group, natives, experience, and membership of CDAs were determinants. .

The R square in this case was $30 \%$. For total use value, education, religion, nationality, ethnic group, and natives were the determinants with $28 \% \mathrm{R}$ Square. From the analysis above, we can conclude that they were most significant in the determinant of total recreation value.

The issue of visitors' determinants of perceived values of mountains and hills for tourism development; for non-use value, education, religion, income, and ethnic group were significant in the determinant of perceived value of mountains and hills for tourism development.
The R Square percentage is $60 \%$. For total recreation value; location, gender, marital status, education, and nationality were significant in the determinant of visitors' perceived values of mountains and hills for tourism development while the level ( $\mathrm{R}$ square) of their determinant is $49 \%$. For total intrinsic value; education, religion, nationality, and activity were significant in the determinant of perceived value of mountains and hills tourism with R Square of $42 \%$. As regard the total use value; religion, ethnic group and activity were significant in the determinant of their perceived value with $\mathrm{R}$ Square of $40 \%$. We can conclude that the perceived value was most significant with the non-use value which had $60 \%$. This was followed by recreation value $(49 \%)$, intrinsic value $(42 \%)$ and use value (40\%).

Table 6: Determinants of communities perceived values of mountains and hills for tourism development Regression Coefficient

\begin{tabular}{|c|c|c|c|c|c|c|c|c|c|c|c|c|}
\hline \multirow{2}{*}{$\begin{array}{l}\text { Independent } \\
\text { variables }\end{array}$} & \multicolumn{2}{|c|}{ Non-use value } & \multicolumn{4}{|c|}{ Recreation value } & \multicolumn{3}{|c|}{ Intrinsic value } & \multicolumn{3}{|c|}{ Use value } \\
\hline & $\beta$ & t-value & Sig. & $\beta$ & t-value & Sig. & $\beta$ & t-value & Sig. & $\beta$ & t-value & Sig. \\
\hline Location & -0.062 & -0.042 & 0.298 & 0.174 & 3.067 & 0.002 & 0.173 & 3.226 & 0.001 & -0.001 & -0.019 & 0.985 \\
\hline Gender & 0.742 & 1.155 & 0.249 & -0.224 & -0.366 & 0.714 & 0.411 & 0.709 & 0.479 & 0.714 & 1.435 & 0.152 \\
\hline Age & -0.893 & -1.441 & 0.150 & 0.309 & 0.522 & 0.602 & -0.192 & -0.3 .44 & 0.731 & -0.122 & -0.255 & 0.799 \\
\hline Marital status & -0.885 & -2.058 & 0.040 & -0.866 & -2.109 & 0.035 & -0.861 & -2.220 & 0.027 & -0.468 & -1.405 & 0.161 \\
\hline Education & -4.681 & -7.421 & 0.000 & -3.922 & -6.511 & 0.000 & -3.807 & -6.693 & 0.000 & -2.979 & -6.094 & 0.000 \\
\hline Occupation & -0.353 & -1.730 & 0.084 & -0.194 & -0.996 & 0.320 & -0.327 & -1.774 & 0.077 & -0.296 & -1.870 & 0.062 \\
\hline Religion & 0.234 & 0.567 & 0.571 & 0.662 & 1.580 & 0.115 & 0.989 & 2.660 & 0.008 & 0.680 & 2.127 & 0.034 \\
\hline Income & -0.019 & -0.050 & 0.960 & -0.097 & -0.272 & 0.786 & -0.370 & 1.096 & 0.274 & 0.084 & 0.289 & 0.773 \\
\hline Nationality & 0.789 & 0.663 & 0.507 & 4.258 & 3.750 & 0.000 & 3.486 & 3.251 & 0.001 & 3.142 & 3.409 & 0.001 \\
\hline Ethnic group & 3.280 & 4.087 & 0.000 & 1.373 & 1.792 & 0.074 & 2.722 & 3.763 & 0.000 & 2.094 & 3.368 & 0.001 \\
\hline Natives & -0.250 & -0.223 & 0.824 & -1.624 & -1.514 & 0.131 & -2.249 & -2.220 & 0.027 & -2.222 & -2.552 & 0.011 \\
\hline Non-Native & -0.075 & -0.431 & 0.667 & -0.118 & -0.713 & 0.476 & 0.199 & 1.276 & 0.203 & 0.063 & 0.469 & 0.639 \\
\hline Years of Stay & 0.484 & 1.878 & 0.061 & 0.126 & 0.511 & 0.609 & 0.102 & 0.440 & 0.660 & 0.097 & 0.488 & 0.626 \\
\hline Years' & 2.797 & 4.370 & 0.000 & 1.882 & 3.080 & 0.002 & 1.315 & 2.278 & 0.023 & 1.438 & 2.898 & 0.004 \\
\hline Experience & & & & & & & & & & & & \\
\hline $\begin{array}{l}\text { Member of } \\
\text { NGOs }\end{array}$ & 1.086 & 0.818 & 0.414 & 1.151 & 0.908 & 0.364 & 0.495 & 1.198 & 0.679 & 0.401 & 0.390 & 0.697 \\
\hline $\begin{array}{l}\text { Member of } \\
\text { CDAs }\end{array}$ & -3.996 & -4.592 & 0.000 & -2.995 & -3.605 & 0.000 & -1.563 & -1.993 & 0.047 & -2.203 & -3.266 & 0.001 \\
\hline $\mathrm{R}$ & 0.52 & & & 0.57 & & & 0.54 & & & 0.53 & & \\
\hline R Square & 0.27 & & & 0.33 & & & 0.29 & & & 0.28 & & \\
\hline $\begin{array}{l}\text { Adjusted R } \\
\text { Square }\end{array}$ & 0.25 & & & 0.31 & & & 0.27 & & & 0.26 & & \\
\hline
\end{tabular}

Table 7: Determinants of visitors' perceived values of mountains and hills for tourism development Regression Coefficient

\begin{tabular}{|c|c|c|c|c|c|c|c|c|c|c|c|c|}
\hline \multirow{2}{*}{$\begin{array}{l}\text { Independent } \\
\text { variables }\end{array}$} & \multicolumn{2}{|c|}{ Non-use value } & \multicolumn{4}{|c|}{ Recreation value } & \multicolumn{3}{|c|}{ Intrinsic value } & \multicolumn{3}{|c|}{ Use value } \\
\hline & $\boldsymbol{\beta}$ & t-value & Sig. & $\beta$ & t-value & Sig. & $\beta$ & t-value & Sig. & $\boldsymbol{\beta}$ & t-value & Sig. \\
\hline Location & 0.562 & 3.944 & 0.000 & 0.276 & 2.159 & 0.031 & 0.165 & 1.366 & 0.173 & 0.210 & 1.928 & 0.055 \\
\hline Gender & -2.753 & -4.022 & 0.000 & -2.485 & -4.046 & 0.000 & -0.724 & -1.247 & -0.213 & -0.954 & -1.820 & 0.069 \\
\hline Age & -1.928 & -3.124 & 0.002 & 1.012 & 1.827 & 0.068 & 0.993 & -1.898 & 0.058 & -1.009 & -2.137 & 0.033 \\
\hline Marital status & -0.903 & -0.634 & 0.527 & -1.133 & -0.887 & 0.376 & 1.089 & 0.909 & 0.364 & -0.387 & -.0356 & 0.722 \\
\hline Education & -0.315 & -0.440 & 0.000 & -2.068 & -3.214 & 0.001 & -1.799 & -2.959 & 0.003 & -0.257 & -0.468 & 0.640 \\
\hline Occupation & -0.189 & -0.688 & 0.492 & -0.757 & -3.066 & 0.002 & -0.230 & -0.985 & 0.325 & -0.388 & -1.844 & 0.006 \\
\hline Religion & -3.028 & -3.354 & 0.001 & -2.593 & -3.201 & 0.001 & -2.477 & -3.235 & 0.001 & -1.905 & -2.757 & 0.006 \\
\hline Income & 1.675 & 6.588 & 0.000 & 1.322 & 5.797 & 0.000 & 0.867 & 4.021 & 0.000 & 0.293 & 1.508 & 0.132 \\
\hline Nationality & -1.489 & -0.353 & 0.724 & 2.721 & 0.719 & 0.473 & -2.809 & -0.785 & 0.433 & -3.465 & -1.073 & 0.284 \\
\hline Ethnic group & -2.333 & -4.472 & 0.000 & -1.081 & -2.310 & 0.021 & -0.785 & -1.775 & 0.077 & -1.325 & -3.319 & 0.001 \\
\hline Travelling & -1.802 & -1.489 & 0.137 & 1.205 & 1.110 & 0.268 & 1.222 & 1.190 & 0.235 & 1.073 & 1.159 & 0.247 \\
\hline Experience & & & & & & & & & & & & \\
\hline $\begin{array}{l}\text { Member of } \\
\text { NGOs }\end{array}$ & -0.789 & -1.008 & 0.314 & 0.484 & 0.689 & 0.491 & -0.459 & -0.691 & 0.490 & 0.328 & 0.548 & 0.584 \\
\hline Motivation & -0.024 & -0.089 & 0.929 & -0.393 & -1.595 & 0.112 & -0.146 & -0.625 & 0.532 & -0.297 & -1.413 & 0.158 \\
\hline $\begin{array}{l}\text { Activity at the } \\
\text { sites }\end{array}$ & -0.926 & -4.523 & 0.000 & -0.526 & -2.864 & 0.004 & -0.679 & -3.908 & 0.000 & -0.344 & -2.194 & 0.029 \\
\hline $\mathrm{R}$ & 0.77 & & & 0.70 & & & 0.65 & & & 0.63 & & \\
\hline $\mathrm{R}^{2}$ & 0.60 & & & 0.49 & & & 0.42 & & & 0.40 & & \\
\hline Adjusted $\mathrm{R}^{2}$ & 0.59 & & & 0.47 & & & 040 & & & 0.37 & & \\
\hline
\end{tabular}


Conclusion: The study will enable the government of Ekiti to partner with the interested individuals and private sector to develop mountains and hills of touristic values in Ekiti communities as swiftly as possible. Secondly, there will be regular communities and visitors tutoring on the benefits of mountains and hills tourism because this will allow all investors to make informed decisions about the types of tourism development and activities that will take place in mountains and hills tourism destinations. Thirdly, there will be effective collaborative networking among mountains and hills investors for the marketing of mountains and hills destinations in Ekiti State as soon as the operation begins. There is need to market the resources of mountains and hills, and put in place public information on mountains and hills facilities that may be illconceived to contradict religious belief of some tourists and visitors. The focus of this study which is 'perceived values of mountains and hills tourism potentials are very relevant to global tourism sector and data could provide information relevant to international visitors, communities and tourists which could enable them to make pre-visit decision when considering the mountains and hills tourism destinations to visit for their pleasure purposes.

\section{REFERENCES}

Debarbieux, B; Gillie, R (2014). 'Tourism in Mountain Regions: Hopes, Fears and Realities Sustainable Mountain Development Series. Geneva, Switzerland: UNIGE, CDE, SDC, pp. 108.

Igbokwe, R (2013). 'Ekiti a rocky State and its untapped potentials'. Retrieved from (http://igbokwerunado.com/ekiti-a-rocky-state-andits-untapped- potentials/on $10^{\text {th }}$ June, 2017

FAO (2016). Food and Agricultural organization: https://fao.org. Retrieved 2nd march, 2020.

Flognfeldt, T; Tjørve, E (2013). The Shift from Hotels and Lodges to Second-Home Villages in MountainResort Accommodation. Scan. J. Hospital. Tourism. 13(4), 332-352.
Mandy, B (2013).The Mountain Environment. Retrieved from http://primaryhomeworkhelp.co.uk>mountains on $5^{\text {th }}$ August, 2017.

Mohd Taher, S.H; Jamal, S. A; Sumarjan, N; Aminudin, $\mathrm{N}$ (2015). Examining the structural relations among hikers' assessment of pull-factors, satisfaction and revisit intentions: The case of mountain tourism in Malaysia. Journal of Outdoor Recreation and Tourism. (12), 82-88.

Tigu, G (2012). New challenges for tourism destination management in Romania. In Murat, K. and Handan, A. (eds) (2012). Strategies for Tourism IndustryMicro and Macro Perspectives. London, United Kingdom: In Tech Open, 167-184

UNEP/PNUMA (2017). 'Mountain Tourism'. https://www.researchgate.net Accessed on $6^{\text {th }}$ July, 2019.

UNWTO (2016). 'UNWTO Tourism Highlights'. Retrieved from http://www.eunwto.org/doi/book/ 10.18111/9789284418145 Tue, Jan. 9th, 2018.

UNWTO (2017). 'Economic Development in Africa Report: Tourism for Transformative Growth'. United Nation NewYork and Geneva.

UNWTO (2020). 'World Tourism Barometer'. http://weunwto.s3.eu-west1.amazonaws.com/../UNWTO barom20-01january-excerpt-0.pd Accessed on $3^{\text {rd }}$ August, 2020. 